\title{
MANAGEMENT OF INSTITUTIONAL AND PREVENTIVE ACTIVITIES IN THE PUBLIC HEALTH SYSTEM OF UKRAINE
}

DOI: 10.36740/WLek202105135

\author{
Iryna M. Khomenko, Oleksandra P. Ivakhno, Yaroslav V. Pershehuba, Ivan P. Kozyarin, Svitlana P. Koshova
}

SHUPYK NATIONAL HEALTHCARE UNIVERSITY OF UKRAINE, KYIV, UKRAINE

\begin{abstract}
The aim: Scientific justification of the public health management methods and instruments for improvement of its effectiveness.

Materials and methods: The authors conducted a complex research of the public health of Ukraine personnel resources development during the system establishment and building. Conclusions: The paper justifies the competence-based model of a specialist (the postgraduate educational level) as well as the university educational standards of the first (bachelor) and second (master) levels of specialty 229"Public health", knowledge branch 22 "Healthcare". The authors have established insufficient level of the youth motivation for obtaining the specialty certification and described disadvantages of both advocacy program within the public health system and its leadership within the preventive system component.

The authors emphasize the necessity of an integrated preventive program maintaining and strengthening the population health, using the advocacy component and available information resources of the public health.
\end{abstract}

KEY WORDS: Public health, operative functions, health promotion

\section{INTRODUCTION}

Establishment of a new professional environment within the public health system of Ukraine is stipulated for the society needs for decreasing infectious diseases burden, fortifying biological safety of the country regarding modern challenges, providing population with healthy life conditions and accessible health service, increasing socioeconomic status of the country as well as its attractiveness for international investment. The development of the preventive service professional capacity through advocacy tendency of the society to the healthcare corresponds to the state policy in general.

The public health system in Ukraine was put on the list of the healthcare institutions (Order of Ministry of Health of Ukraine, issued on 16.05.2018, № 983; registered in the Ministry of Law on 11.06.2018, registration number № $691 / 32143$ «On Introducing Changes to the Healthcare Institutions List»), being the basis of preventive medicine, the development principles of which regard health interests in all state policy branches - disease prevention, increasing longevity and strengthening population health by joint efforts of the society" [1].

\section{THE AIM}

Scientific justification of the public health management methods and principles establishment, aimed at its improved effectiveness.

\section{MATERIALS AND METHODS}

Complex studies of the Ukrainian public health personnel development during the public health system setting up and advancement were held in 2017-2020 in Shupyk National medical academy of postgraduate education.

\section{REVIEW AND DISCUSSION}

Public health in Ukraine has been modified for already first five years. According to the Agreement on Association between Ukraine and European Union, the Community on Atomic Energy and its members, Ukraine is obliged to co-operate with them in the healthcare branch. As a member of the UNO, Ukraine joined the program of Aims of Continuous Development realization through management of the national strategic tasks.

According to the Decree of Cabinet of Ministers of Ukraine issued on 2.09.2015, registration number № 909-p «Issues of Ministry of Health of Ukraine» it was permitted to found the state institution "Center of Public Health". On the $18^{\text {th }}$ of September 2015, the Order of Ministry of Health of Ukraine № 604 approved the "'Regulations of the State Institution "Center of Public Health of Ministry of Health of Ukraine", which was updated in a new version by the Order of Ministry of Health of Ukraine № 515, issued on March 20,2018. Another important milestone was approval by the Decree of Cabinet of Ministers of Ukraine №1002p, issued on 30.11.2016 of "Concept of Public Health 
System Promotion", which defined main challenges in the branch. The Decree of Cabinet of Ministers of Ukraine № 53, issued on 01.02.2017 "On Introducing Changes to the Decree of Cabinet of Ministers of Ukraine № 266 issued on 29.04.2015 "On Approving the List of Study Fields and Specialties of the Undergraduates", included specialty 229 "Public Health" in the branch 22 "Healthcare". This proves attitude of Ukraine to training the public health specialists of the healthcare system [2-5].

The problems of public health establishment are related to different human activity directions, accompanied by various factors, requiring identification of dangerous cause-and-effect relationships for justification of the health-promoting and health-preserving technologies.

Nowadays, the public health system hasn't been "architecturally built" yet, it requires development and establishment regarding the experience of advanced countries and European countries as well as the national peculiarities. There still haven't been defined distinct functions and workloads of the public health specialists, who are studying new standards on their first (bachelor) and second (master) levels, presumably in medical high school establishments [6].

Performing main operative functions in the public health system requires competence of specialists in preventive medicine, epidemiology, hygiene, medical statistics and healthcare management regarding systemic collection, analysis and assessment of the health data, planning the recreative events, defining their usefulness and effectiveness of introduction into the practice [7]. Solving such problems, various state sectors and departments are engaged, which needs consolidated and coordinated activities for the sake of all society health; general governmental approach, which guarantees security of the environment, food products, labour conditions, recreation and medical services quality. The foundation of health base by introduction of immune prevention and healthy lifestyle is defined by the Decrees of Cabinet of Ministers of Ukraine № 530-p , issued on 26.11.2018 "National Schedule of Events for Non-Infectious Diseases" and № 1402-p, issued on 27.11.2019 "Expansion Strategy of Immune Prevention and Population Protection against Infectious Diseases until 2022" [8-11].

Informative and explanatory activities (advocacy), communication and social mobilizing for the sake of health are the most optimum ways of public health problem solving. $[12,13]$. The public health is focused on the collective health, being closely related to various branches of science and practice, with its expressed political character; it has an important social mission - justice and equality of the state citizens. An increased social consciousness level, related to preserving health and a healthy lifestyle promotion in mass media, using information platform which is filled with modern objective and evidence-based content, represent a progressive measure of management of the non-infectious morbidity in Ukraine. The foundation and support of a single information-analytical medical system relies on the public health centers. Providing definite algorithm of the state organs intra-sector cooperation and professional scientific analysis of the results, with their distinct presentation for expert assessment on further management decisions is an important component of the public health system.

An important component of adopting significant decisions within the public health is a state sanitation and hygienic monitoring, approved by the Decree of Cabinet of Ministers of Ukraine № 182 on 22.02.2006 “On Approving the Order of State Sanitation and Hygienic Monitoring" (corrected, according to the Decree of Cabinet of Ministers of Ukraine № 1065, issued on 04.12.2019 and № 826, issued on 09.09 .2020 ) [14]. The monitoring is held by the state, being based on the produced and adopted by the Ministry of Health method, further agreed with the central executive organs, as well as the sanitation regulations and other documents aimed at the sanitation and epidemiological population welfare. The documents are used for making current social-economical prognoses.

The document contains a distinct algorithm of monitoring, the tasks of which are creation of the state information database on population health and human life activity environment, detecting the cause-and-effect relationships, risk assessment, introducing ideas for improving sanitation and epidemiological welfare. The institutions interested in creation of healthy population life activity conditions are the Ministry of Health of Ukraine, Ministry of Regional Construction, Ministry of Agricultural Policy, Ministry of Ecology, Ministry of Emergency Situations, State Water Supply Department. Ministry of Labour, National Academy of Sciences and National Academy of Medical Sciences of Ukraine, and the veterinary medicine institutions. The program must be used by the public health centers on all system management levels. The data of the environmental factor effects (physical, chemical, biological and social) onto the population health are necessary for urgent and long-lasting events of prevention and elimination of the risk factors, advancement of the production technologies as well as the recreate measures.

Using the scientific research data, the authors have detected the necessity for justification of the population health indicative criteria, considering the health service poor availability, introduced changes in the accounting medical documentation and its quality. This relates to the morbidity data, which in $40 \%$ of all cases aren't recorded, thus decreasing value of such information. The foundation and supporting of the common information-analytical system of medical information is a duty of the public health centers. A distinct algorithm of the inter-sector and inter-department state organs interaction, providing the professional scientific analysis of the consolidated results to be presented to experts in order to accept the appropriate decisions. is urgent for the leader positions in public health. (Table 1).

Increasing social consciousness level of health maintenance, promotion of healthy lifestyle and health are considered to be the up-to-date functions of the public health system of Ukraine, which require scientific justification and development of the program, regarding the country peculiarities. 
Table I. Expert assessment of the ways of increasing the public health system significance for maintaining health of population of Ukraine.

\begin{tabular}{cc}
\hline $\begin{array}{c}\text { Ways of increasing the public health system significance } \\
\text { in preventive medicine }\end{array}$ & Significance level, \% \\
\hline 1 & 2 \\
\hline $\begin{array}{c}\text { Public health specialists mobility (Experience exchange } \\
\text { with the leading countries of the world, the EU countries) }\end{array}$ & $93.80 \pm 0.23$ \\
\hline Creating a common unified center of the social-hygienic monitoring & $96.90 \pm 0.08$ \\
\hline Organizing effective communication channels & $75.00 \pm 0.46$ \\
\hline Participation in the pre-nosological determination \\
of the population health changes & $84.20 \pm 0.37$ \\
\hline Promoting healthy lifestyle for the country population & $92.60 \pm 0.25$
\end{tabular}

Introduction of changes into the educational standard, considering the European and international experience for the advocacy system content within the public health system is a priority direction of this modern branch in Ukraine.

According to the conducted studies, the authors have justified a competence-based model of a specialist (the postgraduate educational level) as well as the university educational standards of the first (bachelor) and second(master) levels of specialty 229 "Public health" of the knowledge branch 22 "Healthcare".

\section{CONCLUSIONS}

The necessity of establishment of the integrated preventive system of maintaining and strengthening the population health, using the advocacy component and available information resources of the public health system represents a significant and urgent issue in Ukraine.

\section{REFERENCES}

1. Nakaz Ministerstva okhorony zdorovia Ukrainy vid 16 travnia $2018 \mathrm{r}$. za № 983. Zareiestrovano v Ministerstvi yustytsii Ukrainy 11 chervnia 2018 r. za № 691/32143 «Pro vnesennia zmin do pereliku zakladiv okhorony zdorovia» [Order of the Ministry of Health of Ukraine dated May 16, 2018 for № 983. Registered in the Ministry of Justice of Ukraine on June 11,2018 for № $691 / 32143$ «On amendments to the list of health care facilities»]. (in Ukrainian).

2. Rozporiadzhennia Kabinetu Ministriv Ukrainy vid 2 veresnia 2015 roku № 909-r «Pytannia Ministerstva okhorony zdorovia» [Order of the Cabinet of Ministers of Ukraine of September 2, 2015 № 909-r «lssues of the Ministry of Health»]. (in Ukrainian).

3. Order of the Ministry of Health of Ukraine September 18, 2015 № 604 "Statute of the State Institution" Public Health Center of Ukraine" (As amended by the order of the Ministry of Health of Ukraine June 30, 2020 № 1483) [Order of the Ministry of Health of Ukraine September 18, 2015 № 604 “Statute of the State Institution“ Public Health Center of Ukraine" (As amended by the order of the Ministry of Health of Ukraine June 30, 2020 № 1483)]. (in Ukrainian).

4. Order of the Cabinet of Ministers of Ukraine of November 30, 2016 № 1002-r «On approval of the Concept of development of the public health system» [Order of the Cabinet of Ministers of Ukraine of November 30, 2016 № 1002-r «On approval of the Concept of development of the public health system»]. (in Ukrainian).
5. Postanova Kabinetu Ministriv Ukrainy vid 1 liutoho 2017 roku № 53 «Pro vnesennia zmin do Postanovy Kabinetu Ministriv Ukrainy vid 29 kvitnia 2015 roku № 266 «Pro zatverdzhennia pereliku haluzei znan i spetsialnostei, za yakymy zdiisniuietsia pidhotovka zdobuvachiv vyshchoi osvity v haluzi «22 Okhorona zdorovia» [Resolution of the Cabinet of Ministers of Ukraine of February 1, 2017 № 53 «0n Amendments to the Resolution of the Cabinet of Ministers of Ukraine of April 29, 2015 №266» On approval of the list of branches of knowledge and specialties for higher education in the field of «22 Health Care»]. (in Ukrainian).

6. Nakaz Ministerstva okhorony zdorovia Ukrainy 12 hrudnia 2018 r. № 1383 «Pro zatverdzhennia standartu vyshchoi osvity za spetsialnistiu 220 «Hromadske zdorovia» dlia druhoho (mahisterskoho) rivnia vyshchoi osvity» [Order of the Ministry of Health of Ukraine December 12, 2018 № 1383 «0n approval of the standard of higher education in the specialty 220» Public Health «for the second (master's) level of higher education»]. (in Ukrainian).

7. Gulchiy O.P., Khomenko I.M., Zakharova N.M. et al. Metodychni pidkhody do pidvyshchennia efektyvnosti kompetentnisnoi modeli pidhotovky spetsialistiv z hromadskoho zdorovia v Ukraini [Methodical approaches to increase education efficiency in specialists of public health of Ukraine]. Wiadomosci Lekarskie, 2018; 7: 1336-41. (in Ukrainian).

8. Rozporiadzhennia Kabinetu Ministriv vid 26 lystopada 2018 r. № 530-r «Natsionalnyi plan zakhodiv shchodo neinfektsiinykh zakhvoriuvan» [Order of the Cabinet of Ministers of November 26, 2018 № 530-r «National Action Plan on Noncommunicable Diseases»]. (in Ukrainian).

9. Rozporiadzhennia Kabinetu Ministriv Ukrainy № 1402-rvid 27 lystopada 2019 r. «Stratehiia rozvytku imunoprofilaktyky ta zakhystu naselennia vid infektsiinykh khvorob na period do 2022 roku» [Order of the Cabinet of Ministers of Ukraine № 1402-r of November 27,2019 «Strategy for the development of immunoprophylaxis and protection of the population from infectious diseases until 2022»]. (in Ukrainian).

10. Postanova Verkhovnoi Rady Ukrainy vid 14.01.2020 № 454-IKh «Pro provedennia parlamentskykh slukhan na temu «Orhanizatsiia protyrakovoi borotbi v Ukraini. Problemy ta shliakhy yikh vyrishennia» [Resolution of the Verkhovna Rada of Ukraine of 14.01.2020 № 454-IX “On holding parliamentary hearings on the topic" Organization of anti-cancer fight in Ukraine. Problems and ways to solve them»]. (in Ukrainian).

11. Postanova Verkhovnoi Rady Ukrainy vid 14.01.2020 № 454-IX «Pro provedennia parlamentskykh slukhan na temu «Orhanizatsiia protyrakovoi borotbi v Ukraini. Problemy ta shliakhy yikh vyrishennia» [Resolution of the Cabinet of Ministers of Ukraine of December 12, 2019 № 374-IX «On adoption as a basis of the draft Law of Ukraine on Amendments to Certain Laws of Ukraine on Prevention of Adverse Effects of Air Pollution on Public Health»]. (in Ukrainian). 
12. Slabkyi H. 0., Myroniuk I. S., Shafranskyi V. V. Epidemiolohichnyi nahliad yak osnovna funktsiia hromadskoho zdorovia [Epidemiological surveillance as the main function of public health]. Ukraine. Health of the Nation. 2017; 4: 97-100. (in Ukrainian).

13. Hushchuk I. V., Anchyshkin A. I., Voloshchuk 0.V. Stratehichni napriamy rozbudovy systemy okhorony hromadskoho zdorovia Ukrainy [Strategic directions of development of the public health care system of Ukraine]. Environment and Health. 2020; 3: 4-9. (in Ukrainian).

14. Postanova Kabinetu Ministriv Ukrainy vid 22 liutoho 2006 r. № 182 «Pro zatverdzhennia Poriadku provedennia derzhavnoho sanitarnohihiienichnoho monitorynhu» (Iz zminamy, vnesenymy zghidno z Postanovamy Kabinetu Ministriv № 1065 vid 04.12.2019 r., № 826 vid 09.09.2020 r.) [Resolution of the (abinet of Ministers of Ukraine of February 22, 2006 № 182“0n Approval of the Procedure for Conducting State Sanitary and Hygienic Monitoring" (As amended in accordance with the Resolutions of the Cabinet of Ministers № 1065 of 04.12.2019, № 826 of 09.09.2020)]. (in Ukrainian).

The article was prepared in frames of the theme "Scientific and methodological justification of the personnel capacity development within the public healthcare system in Ukraine."

\section{ORCID and contributionship:}

Iryna M. Khomenko: 0000-0002-8412-6393 A, B, C, D, E, F

Oleksandra P. Ivakhno: 0000-002-2418-425X A, B, C, D, E, F

Yaroslav V. Pershehuba: 0000-0003-4592-3047 A, B, C, D, E, F

Ivan P. Kozyarin: 0000-0002-9873-8227 A, B, C, D, E, F

Svitlana P. Koshova: 0000-0002-7637-4311 A, B, C, D, E, F

\section{Conflict of interest:}

The Authors declare no conflict of interest.

\section{CORRESPONDING AUTHOR Iryna M. Khomenko}

Shupyk National healthcare university of Ukraine, 9 Dorohozhytska Str., 04112 Kyiv, Ukraine tel: +380962375460 e-mail: khomen2010@ukr.net

Received: 14.12 .2020

Accepted: 02.04 .2021

A - Work concept and design, B - Data collection and analysis, C - Responsibility for statistical analysis, D-Writing the article, $\mathbf{E}$-Critical review, $\mathbf{F}$ - Final approval of the article 